\title{
Time for action. Implementing the New Urban Agenda in public spaces for health and wellbeing
}

\author{
Gregor H. Mews \\ Urban Synergies Group / University of Canberra, Health Research Institute \\ Gregor@urbansynergiesgroup.org \\ Milica Muminovic \\ University of Canberra, Faculty of Arts and Design \\ Milica.Muminovic@canberra.edu.au \\ Paul Tranter \\ University of New South Wales Canberra, School of Physical Environmental and Mathematical Sciences \\ p.tranter@adfa.edu.au
}

Urban Agendas are important guiding tools that frame thinking and point to major directions and changes needed. The dominant planning and city development practices in the $20^{\text {th }}$ century resulted in the proliferation of modern cities that brought numerous problems that urban planners and designers are still dealing with. Do we have the capacity and appropriate tools to change the cities of tomorrow to make them more liveable places?

The challenges may seem overwhelming. However, there are advantages in strategies that combine acting locally and synergising with other places. Using insights from the Urban Synergies Group this paper represents a summary of initial pathways that may effectively implement the NUA (New Urban Agenda) - a collective vision for sustainable and healthy cities. To address the main issues of the NUA we discuss five key themes. First, we consider the level of commitment to achieve healthier cities for all during the $9^{\text {th }}$ World Urban Forum (WUF 9). Second, we narrow our focus to examine child health and wellbeing. Third, we introduce an exemplary collaboration that harnesses collective wisdom through empowerment of participants. Fourth, we provide the rationale for the focus on public space. Within the fifth point we summarise tangible actions within the nexus of child health and public space that help to implement the NUA on the ground.

Keywords: public space, play, health and wellbeing, children, New Urban Agenda

To cite this article:

Mews, G. H., Muminovic, M. and Tranter, P. (2018). Time for action. Implementing the New Urban Agenda in public spaces for health and wellbeing. The Journal of Public Space, 3(I), 193-202. DOI: 10.5204/jps.v3il.330

This article has been accepted for publication in The Journal of Public Space. Please see the Editorial Policies under the 'About' section of the journal website for further information.

(7) 8 This work is licensed under a Creative Commons Attribution - Non Commercial 4.0 International License - https://creativecommons.org/licenses/by-nc/4.0/ 
The United Nations predicts that the world population will nearly double by 2050 (United Nations, 2017). People move to cities, not only locally within the national borders, but also globally, in hopes for a better quality of life for themselves and for the next generation. Mass migrations from rural to urban areas have created challenges for cities, which town planners and urban designers alone seem unable to resolve comprehensively in order to enable sustainable, economically well-balanced and healthy living environments for all. While many nations have experienced mass migrations, the resulting challenges are diverse and require revisiting current urban planning and design practice.

The international community came together at the United Nations Conference on Human Settlement (Habitat III) in Quito, Ecuador, in 2016 to readdress the way we plan, design, develop, manage and govern urban systems. The outcome was the New Urban Agenda (NUA): a document that sets out nonbinding commitments and the collective vision for an integrated sustainable urban development that will be achieved by the implementation of the 2030 Agenda with its Sustainable Development Goals (United Nations, 2017). During the $9^{\text {th }}$ World Urban Forum (WUF 9) 22,000 interdisciplinary stakeholders from 164 different countries came together showcasing their commitment to help implementing the NUA (UN-Habitat, 2018). This included the Urban Synergies Group (Mews, 2018). In this paper we reflect on the proactive involvement of this group during the event and discuss the nexus between health and wellbeing of future generations and the implications for public space.

The NUA has health as a key focus and WUF 9 should have been the opportunity to demonstrate this achievement. If citizens today seek to enable a healthy future for the next generation, new partnerships are required. Public spaces are the domain where necessity meets possibility, while the quality and appropriation become the measure of success. Genuine collaboration can enable tangible actions for and with children.

\section{World Urban Forum and healthy cities}

Concerted advocacy efforts of key stakeholders during Habitat III and the commitment by the World Health Organisation (WHO) led to the identification of health as the "pulse" of the NUA. Further the Sustainable Development Goals (SDG's) illustrate the potential for strong synergies between SDG 3 - Good health and wellbeing, SDG 10 - Reduced Inequalities, SDG II - Sustainable Cities and Communities as well as SDG I7 - Partnerships for the goals towards tangible actions on a local level. With this in mind the WUF 9 could have been the ideal opportunity to demonstrate a snapshot of the "pulse" of health across cities on planetary level.

Unfortunately, this "pulse" was beating at a low rate and remained hidden from most participants. Detailed actions and learnings from cities where positive examples of the "pulse" are evident in tangible evidence-based action in relation to public health and urban design remain fragmented. Overall, this "pulse" needs to beat at a satisfactory rate if we want to enable the much-needed seismic shift that is required to implement the collective vision set out in the NUA in a meaningful way.

Problems of urban health are evident in low levels of physical activity (and associated high levels of overweight, obesity, type 2 diabetes and heart disease), and high ecological footprints that are increasing at the same time as quality of life measures are decreasing. These trends support the recognition of the need to question the effectiveness of following current trends toward economic growth evident in high income countries. In

I94 | The Journal of Public Space, 3(I), 20I8 | ISSN 2206-9658 
the absence of leadership on national scale, context specific actions are required to address the needs of people in cities and towns on bioregional and local scales. A healthy city is one that continually creates and improves physical and social environments, while it expands those community resources that enable people to mutually support each other when it comes to performing all functions relating to life and development to their full potential (World Health Organisation, 1998). These arguments can be seen clearly when focussing on child health and wellbeing.

\section{Child health and wellbeing}

Children are the natural experts of the local environment in which they grow up in and should be treated as such (Mews, 2018). Children are a kind of "indicator species for cities" (Gill, 2017). The British writer and children's researcher Tim Gill explains that when children of all ages are visibly present in neighbourhoods, this is a sign of a healthy human habitat, in much the same way that salmon indicate the health of rivers. Children have also been described as being like canaries in the mines (Gleeson \& Sipe, 2006): they are the group who are most likely to disappear from the streets as societies change and are perceived as more dangerous.

If we are collectively committed to creating a healthier and sustainable urban future, cities should enable spaces where children can develop to their full potential. However, evidence suggests that the way we currently operate urban systems is far from providing environments that enable healthy childhood development. One of the main issues in modern western societies is that children's wellbeing is considered to be the individual responsibility of parents and families. For example, when traffic danger is seen as an issue, parents respond as individuals to keep their children safe by driving them to school and to other locations. The collective impact of this is to make cities more dangerous for all citizens. What is needed is a collective response that makes the whole environment, particularly public spaces, safer and more attractive for children (and adults).

The total mortality rate of children due to a road traffic collision is estimated to 10.7 per 100,000 population and 90 percent of those accidents occur in middle and low-income countries (World Health Organisation, 2008). In contrast growing up in a risk-averse high income society can equally result in damaging effects on children (Gill, 2007; Renz-Polster \& Hüther, 20l3). Serious cardio-metabolic disorders and mental health issues such as depression have been on the rise in adolescence and in early adulthood (Herrington \& Brussoni, 20I5; Sallis, Prochaska, \& Taylor, 2000; Salmon, Owen, Crawford, Bauman, \& Sallis, 2003; Tremblay et al., 20I5). The level of physical inactivity is so high that children rarely achieve the global recommendation of 60 minutes of moderate to rigorous physical activity every day (World Health Organisation, 2010), which is associated with overweight and obesity. For example in Canberra, Australia, around quarter of children are now classified over a healthy weight (ACT Government, 20I4) and sport alone does not deliver the desired public health outcomes for the next generations on large scale. Incidental physical activity as part of people's everyday life routine such as walking, cycling as well as the opportunity to play independently become increasingly important. Malone described the current state of cities as "overcrowded, unsafe and polluted environments which provide little room for learning, play and recreation" (Malone, 200 I, p. 9). Traffic congestion is estimated to get worse (World Health Organisation, 2008), public spaces are increasingly contested (Bravo, Carmagnini, \& Matityhou, 2013; Iveson, 
1998; Manfredini, Gharaghooshi, \& Leardini, 20I7; Mierzejewska, 20II; Tieben, 20I6), and perceived shifts in safety prevent children from exploring the city on their terms (Tranter, 2006; 2014; Valentine \& McKendrick, 1997; Wyver et al., 2010).

\section{A case study for collaboration: a side network event on "Shaping healthy cities for and with children"}

During WUF 9, together with our partners City Space Architecture, the Chinese University of Hong Kong, University of Auckland, International Play Association, World Urban Campaign, University of Melbourne and the University of Canberra Health

Research Institute, the Urban Synergies Group hosted a side network event that aimed to create synergies between children rights, health and wellbeing and public space. 60 people from nations around the world took part in this collaborative event entitled "Shaping healthy cities for and with children".
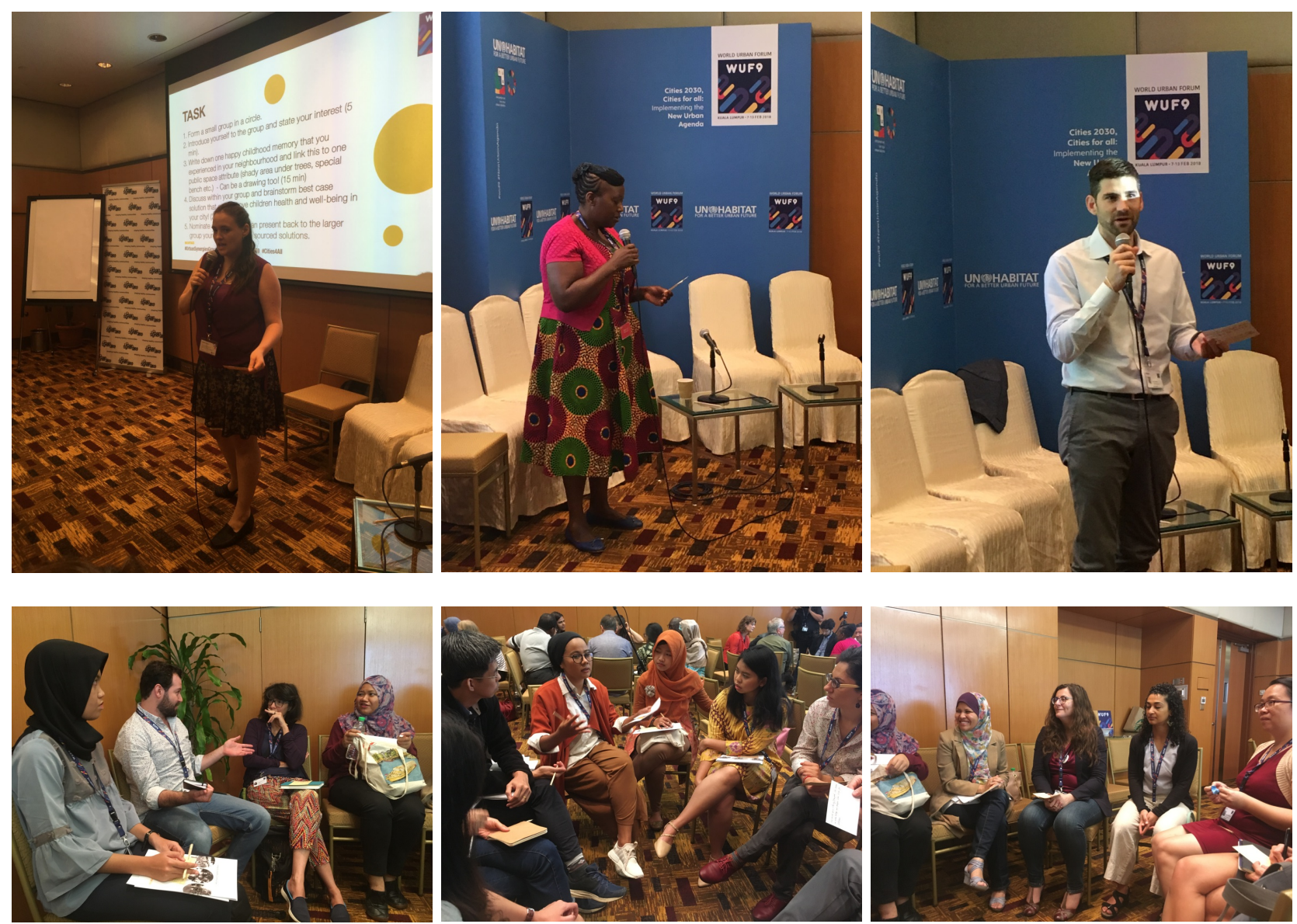

Fig. I-6. Networking event at 9th World urban Forum. Images by Urban Synergies Group.

The objective was to bring together an interdisciplinary group of thought leaders and key advocates to drive positive change for child health and wellbeing in cities. This included a panel of leading thinkers on public space and distinguished advocates for children's rights. The evidence presented on international case studies and the lived experience of all participants enabled us to create an environment for knowledge exchange and a spirit of

196 | The Journal of Public Space, 3(I), 2018| ISSN 2206-9658

City Space Architecture / Queensland University of Technology / UN-Habitat 
genuine collaboration. A strong emphasis was placed on the harnessing of the collective wisdom in the room through workshop group discussions and short feedback presentations by the participants. This led to the identification of tangible actions such as safe independent childhood mobility (walking and cycling), encounter with nature in public space, and design for connected play spaces for all. All of these can be instrumental in driving change, empowerment of children and adolescents while fostering new partnerships.
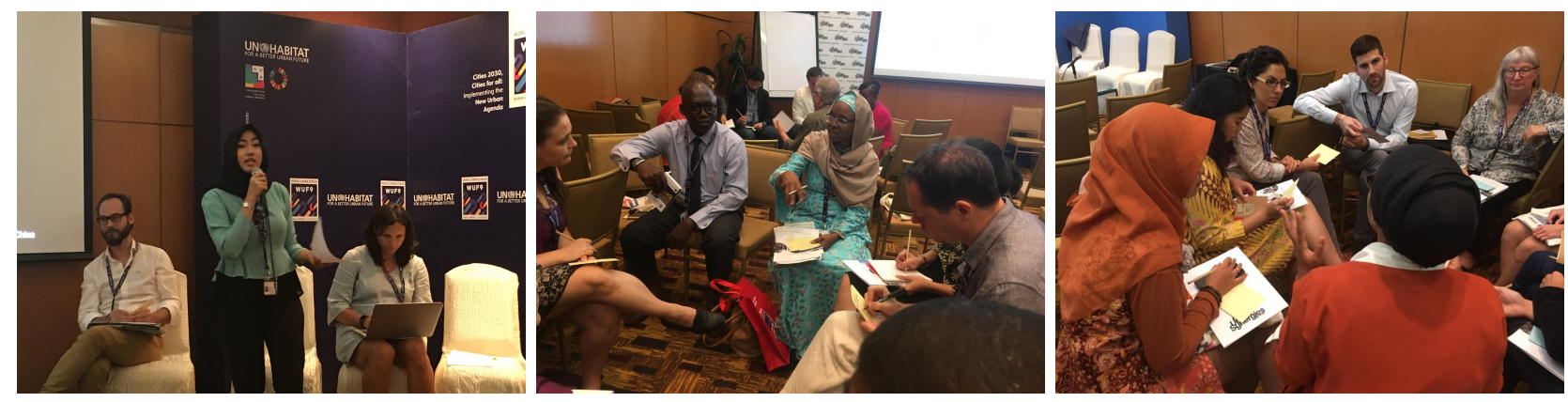

Fig. 7-9. Networking event at 9th World urban Forum. Images by Urban Synergies Group.

\section{Public space}

The focus of this side network event was public space. The straightforward way to take action and start addressing the issues discussed here is in public domain. In order to engender support for change, urban governments need to start from what is a generally desirable goal. To implement the NUA we need to make space for the public and we also need to provide high quality public spaces so that all the actors can take conscious action in that space. With increasing proliferation of semi-public spaces and neoliberal "spectaclerisation" of the city the privately owned shopping mall and gated communities becomes the ultimate consumption mechanism of public space (Debord, 1994; Knapp, 2006). We recognise that we need to rediscover the traditional plaza. In addition, we need to go beyond consumerism and spectacle in making public spaces meaningful places for people. The new public experience needs to be immersive, experiential and sensual. As Harvey (2008) suggest “... it is a right to change ourselves by changing the city" and not mere existence and accessibility of public spaces.

In a liveable, vibrant and sustainable city, public spaces need to inspire people for healthy living; they need to provide identity, which will merge together the identity of the place collectively with people's identities. The public space should evoke positive emotions towards the city. This new public space provides a setting for activities, imagination, creativity and ultimately play. The extent to which these are evident in public space will be the measure of the success of a new vision for the city.

\section{WUF 9 - Findings from "Shaping healthy cities for and with children"}

In relation to intervention in public spaces, participants in the networking event cocreated and brainstormed a series actions that can lead to effective outcomes on the ground. The following five tangible actions were the most frequently mentioned during the workshop and strongly echo the collective wisdom of all participants and thought 
leaders (Mews, Cochrane, Davey, 2017). The first action relates to the awareness of the importance of Children's Right to Play with Article 12 \& 31 of the UN Convention on the Rights of the Child (United Nations, 1989) acknowledging the need to empower children and to co-create with them (Hart, 2013; Shier, 200I). The second action focuses on the reduction of motorised traffic speeds and the amount of traffic on local neighbourhood streets, and the protection and enhancement of public open spaces through co-designed place-making interventions with and for children in cities. The loss of independent mobility during childhood, and the lack of safe access to attractive outdoor spaces for free play, highlight the need for context and culturally appropriate place-making initiatives.
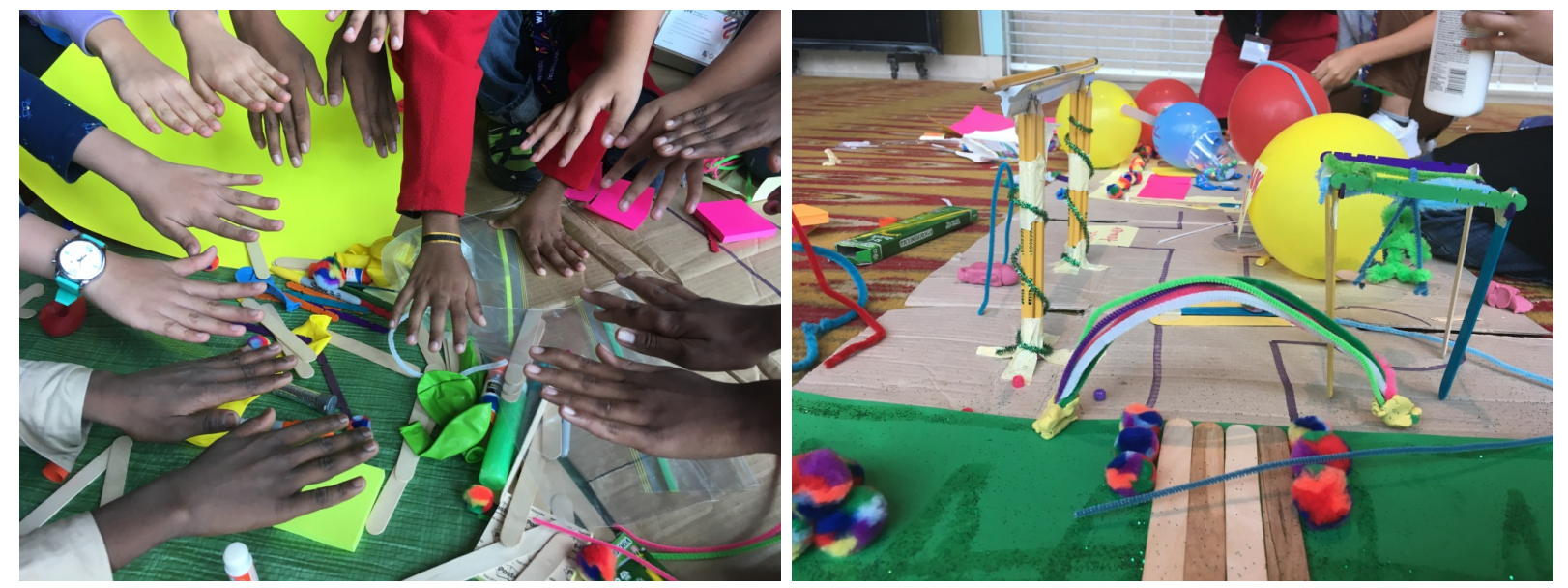

Fig. 10-II. Workshop with children at 9th World urban Forum. Images by Urban Synergies Group.

Evidence suggests that effective place-making can enable better health outcomes and increase the level of social inclusion and exchange ( $\mathrm{Ng}, 2016$; O'Brien, Jones, \& Rustin, 2000; Veitch, Bagley, Ball, \& Salmon, 2006). Successful policy responses include the creation of low speed or even vehicle-free spaces for safe play and independent active travel (Page, Cooper, Griew, \& Jago, 2010; Tranter, 2014; Vallée, Cadot, Roustit, Parizot, \& Chauvin, 20II). Alternatively, the emphasis on natural play spaces with loose elements can foster developmental opportunities for creativity and imagination in children (Bundy et al., 20II; Spencer \& Wright, 20l4). By reducing the number of artificial surfaces and plastic components in play spaces, heat islands and exposure to potentially hazardous fumes can be reduced (Lopes, Blick, \& Pfausch, 2018). Natural spaces for free outdoor play are essential for healthy childhood development, in addition to the benefits of physical activity (Fjørtoft, 200I; Herrington \& Brussoni, 20I5; Seeland, Dübendorfer, \& Hansmann, 2009; Spencer \& Wright, 20I4). Furthermore, the air quality indoors is often worse than outdoors, and thus the increasing number of indoor play spaces is of concern (Jones, 1999; Tham, 2016).

The third action refers to urban tree planting initiatives (green oases for healthy child play) to counteract heat islands, to enhance air quality and micro climate as well as providing additional play opportunities for children (Mews, 2018). The fourth action relates to the rediscovery of design for feeling, life and provision of safe infrastructure. Spaces that have a sense of place are a perceived playground for rich stimulation and social exchange and even tensions, where feelings can be expressed reflecting all facets of 
life. If we seek successful public spaces for all we need to better understand the complexity of how a place is experienced. Muminovic (2016) suggests that understanding "place identity" (the complex relationships between all the elements of the place) can promote a better understanding of public spaces and how the character of these places changes over time.

The fifth action highlights an emerging issue in relation to the impact of modern technologies (e.g. smart phones devices, tablets, WIFI use) that overwrite the physicality of public spaces. The potential impacts of these technologies and their long-term implications for social dynamics and health and wellbeing are not well understood. The thought leaders in the room stressed that this urgently requires attention, so that policy makers can make better informed decisions and ensure public spaces provide health and wellbeing benefits not just for children but for all generations (Mews, 2018).

\section{Conclusion}

The arguments in this paper indicate that the challenges we face collectively as a species require an evolutionary shift in thinking and new approaches to the way we co-create and design cities. The NUA is an agreed document that formally acknowledges the shared vision of how the international community shall design the city we all need until 2030. Since we are now in the implementation phase of the NUA, the $9^{\text {th }}$ World Urban Forum provided a platform for knowledge exchange, while being conceived as the ideal opportunity to form novel partnerships for action. The Urban Synergies Group has been given the opportunity to be a proactive player, is committed to implementing the NUA with the spirit of genuine partnership in relation to health and wellbeing and public space. Our findings demonstrate international stakeholders and passionate individuals are not short of innovative and evidence-based ideas about tangible actions that can lead to better outcomes for children's health and wellbeing in cities. However, our reflections on WUF 9 highlight that to achieve better health and wellbeing outcomes in cities the collective efforts need to be strengthened. It is hoped that WUF 10 will have a stronger more articulate "pulse" on health, where novel synergies will emerge with constituency groups, including visionary philanthropist, funding agencies and media partners which have been largely missing until now. Evidence suggests that concrete commitments can be implemented in an environment where innovative leadership empowers grassroots communities, and academic rigour informs better decision-making processes. Public spaces are and need to be the realm for social encounter. A realm where love, play, compassion, creativity, and fulfilling experiences can take place and enable space identities that meet the needs and desires of children as the indicator species for healthy urban spaces. In those spaces rules can and should be able to be contested, while we seek pathways for a collective realisation that health and wellbeing is a continuous process that starts with the rediscovery of the beauty of everyday life experiences in public spaces. Genuine partnership with stakeholders can drive change leading to actions that address spatial and non-spatial attributes, which can help create public spaces that promote wellbeing. The time for action is now. 


\section{References}

ACT Government. (20I4). Chief Health Officers Report Retrieved from Canberra.

Bravo, L., Carmagnini, C., \& Matityhou, N. (2013). Lighter, Quicker, cheaper: towards an Urban Activism Manifesto, in Sbetti, F., Rossi, F., Talia, M. and Trillo, C. (eds.), Il governo della città nella contemporaneità. La città come motore di sviluppo, "Urbanistica on line", Dossier n. 4, XXVIII INU Congress proceedings, INU Edizioni, Roma, pp. 33-36.

Bundy, A. C., Naughton, G., Tranter, P., Wyver, S., Baur, L., Schiller, W., . . Brentnall, J. (20II). The Sydney playground project: popping the bubblewrap - unleashing the power of play: a cluster randomized controlled trial of a primary school playground-based intervention aiming to increase children's physical activity and social skills. BMC Public Health, I I:680.

Debord, G. (1994). The Society of the Spectacle (D. Nicholson-Smith, Trans.). Camebridge \& London: MIT Press.

Fjørtoft, I. (200I). The natural environment as a playground for children: The impact of outdoor play activities in pre-primary school children. Early childhood education journal, 29(2), I I I-I I 7.

Gill, T. (2007). No Fear: growing up in a Risk Averse Society. London: Calouste Gulbenkain Foundation.

Gill, T. (2017, 18 July 20I7). Crucial indicator for a successful, healthy city: Children. The Inquirer.

Gleeson, B., \& Sipe, N. (2006). Creating child friendly cities : reinstating kids in the city. London ; New York: Routledge.

Hart, R. (20I3). Children's participation: The theory and practice of involving young citizens in community development and environmental care: Routledge.

Harvey, D. (2008). The right to the city. The City Reader, 6, 23-40.

Herrington, S., \& Brussoni, M. (20I5). Beyond Physical Activity: The Importance of Play and Nature-Based Play Spaces for Children's Health and Development. Current Obesity Reports, 4(4), 477-483. doi: 10.1007/s 13679-015-0179-2

Iveson, K. (1998). Putting the public back into public space. Urban Policy and Research, 16(I), 21-33. Jones, A. P. (1999). Indoor air quality and health. Atmospheric Environment, 33(28), 4535-4564. doi:https://doi.org/I0.1016/S1352-2310(99)00272-I

Knapp, K. (2006). Situationist International Anthology Berkley, CA: Bureau of Public Secrets.

Lopes, M. L., Blick, M., \& Pfausch, S. (2018). Material that make heat worse for our kids demand a rethink by designers. Retrieved from the conversation website:

http://theconversation.com/materials-that-make-heat-worse-for-our-kids-demand-a-rethink-bydesigners-93274

200 | The Journal of Public Space, 3(I), 20I8 | ISSN 2206-9658

City Space Architecture / Queensland University of Technology / UN-Habitat 
Malone, K. (200I). Children, Youth and Sustainable Cities. Local Environment, 6(I), 5-I2. doi: $10.1080 / 13549830120024215$

Manfredini, M., Gharaghooshi, F. Z., \& Leardini, P. (2017). Instances of emerging agonistic spatialities in the contemporary city the production of differential geographies in the public space of Istanbul. Asian Journal of Humanities and Social Studies (ISSN: 232 I-2799), 5(05).

Mews, G. (2018). Shaping Healthy Cities for and with Children: Side Networking Event Report. Retrieved from Canberra, Australia and Kuala Lumpur, Malaysia: https://urbansynergiesgroup.org/wp-content/uploads/2018/03/WUF9-Report.pdf

Mews, G., Cochrane, T., Davey, R. (2017). Shaping Spaces for Gen Z - International Forum Report: Urban Thinkers Campus. (978-0-9954095-2-I, 0-9954095-2-8, ). Retrieved from Canberra, Australia: https://urbansynergiesgroup.org/wp-content/uploads/2017/05/SS4GenZReport Web.pdf

Mierzejewska, L. (20II). Appropriation of Public Urban Space as an Effect of Privatisation and Globalisation. In Quaestiones Geographicae (Vol. 30, pp. 39).

Muminovic, M. (2016). Place identity and sustainable urban regeneration: Public space in Canberra City Centre. Urban Regeneration \& Sustainability, 374.

$\mathrm{Ng}, \mathrm{M}$. K. (2016). The right to healthy place-making and well-being. Planning Theory \& Practice, I 7(I), 3. Doi:10.1080/I4649357.2016.1I39227

O'Brien, M., Jones, D., \& Rustin, M. (2000). Children's independent spatial mobility in the public realm. Childhood, 7. Doi: I0.I I77/0907568200007003002

Page, A. S., Cooper, A. R., Griew, P. J., \& Jago, R. (2010). Independent mobility, perceptions of the built environment and children's participation in play, active travel and structured exercise and sport: the PEACH Project. International Journal of Behavioral Nutrition and Physical Activity, 7.

Renz-Polster, H., \& Hüther, G. (20I3). Wie Kinder heute wachsen (How children grow today, Trans.). Weinheim \& Basel: Beltz.

Seeland, K., Dübendorfer, S., \& Hansmann, R. (2009). Making friends in Zurich's urban forests and parks: The role of public green space for social inclusion of youths from different cultures. Forest Policy and Economics, I I(I), I0-17. Doi:10.1016/j.forpol.2008.07.005

Shier, H. (200I). Pathways to Participation: Openings, Opportunities and Obligations: A New Model for Enhancing Children's Participation in Decision-Making, in Line with Article 12.I of the United Nations Convention on the Rights of the Child. Children \& Society, I5(2), 107-II 7.

Spencer, K. H., \& Wright, P. M. (2014). Quality Outdoor Play Spaces for Young Children. Young Children, 28-34.

Tham, K. W. (2016). Indoor air quality and its effects on humans-A review of challenges and developments in the last 30 years. Energy and Buildings, 130, 637-650.

Doi:https://doi.org/10.1016/j.enbuild.2016.08.07| 
Tieben, H. (2016). Public Space Trends in Hong Kong. A view from the New Territories. The Journal of Public Space, I(I), 25-34.

Tranter, P. (2006). Overcoming social traps: a key to creating child friendly cities. In B. Gleeson, Sipe, N., (Ed.), Creating child friendly cities: reinstating kids in the city (pp. I2I - 135). Oxon, Canada, New York, USA: Routledge.

Tranter, P. (2014). Active Travel: A Cure for the Hurry Virus. Journal of Occupational Science, 2I(I), 65-76. Doi:I0.1080/I442759I.20I3.865I53

UN-Habitat. (2018). The Ninth session of the World Urban Forum. Retrieved from Nairobi: http://wuf9.org/wp-content/uploads/presentation/Post-WUF9-presentation.pdf

United Nations. (1989). Convention on the Rights of the Child. General Assembly Resolution 44/25 of 20th November 1989. Retrieved from http://www.ohchr.org/en/professionalinterest/pages/crc.aspx

United Nations. (20I7). New Urban Agenda (H. I. Secretariat Ed.). Quito, Ecuador UN-Habitat.

Valentine, G., \& mckendrick, J. (1997). Children's Outdoor Play: Exploring Parental Concerns About Children's Safety and the Changing Nature of Childhood. Geoforum, 28(2), 219-235.

Vallée, J., Cadot, E., Roustit, C., Parizot, I., \& Chauvin, P. (201I). The role of daily mobility in mental health inequalities: The interactive influence of activity space and neighbourhood of residence on depression. Social Science \& Medicine, 73(8), II I33-I I 44.

Doi:10.1016/j.socscimed.2011.08.009

Veitch, J., Bagley, S., Ball, K., \& Salmon, J. (2006). Where do children usually play? A qualitative study of parents' perceptions of influences on children's active free-play. Health \& Place, 12(4), 383-393. Doi:http://dx.doi.org/10.1016/j.healthplace.2005.02.009

World Health Organisation. (1998). Health Promotion Glossary. Retrieved from Geneva, Switzerland: http://www.who.int/healthpromotion/about/HPR\%20Glossary\%201998.pdf?Ua=I

World Health Organisation. (2008). World report on child injury prevention Retrieved from Geneva, Switzerland http://apps.who.int/iris/bitstream/handle// 0665/4385I/978924I563574_eng.pdf?Sequence= I

World Health Organisation. (2010). Global recommendation on physical actitivity for health Retrieved from www.who.int

Wyver, S., Tranter, P., Naughton, G., Little, H., Sandseter, E. B. H., \& Bundy, A. (20I0). Ten ways to restrict children's freedom to play: The problem of surplus safety. Contemporary Issues in Early Childhood, I I (3), 263-277. 